\title{
GLL
}

Geomatics, Landmanagement and Landscape No. $2 \cdot 2019,153-164$

\section{PROBLEMS OF TOURISM DEVELOPMENT OF SEA-COAST ZONES, AS ILLUSTRATED WITH THE EXAMPLE OF USTKA TOWN}

\author{
Michał Uruszczak
}

\section{Summary}

The town of Ustka is a health resort located in Central Pomerania, situated within the coastal zone, and serving tourism, agricultural and forest functions in this region of Poland. Spatial development resulting from the immediate vicinity of the sea and related environmental conditions is visible within the space, which is the subject of the present analysis. The fragment of the coastal zone, which functions as the main area of recreation and leisure within the town of Ustka, has been examined. The article presents the analysis of the particular features typifying the local development of the eastern part of the Baltic coast belt in the town of Ustka, as well as its general evaluation, and indication of the possibilities for tourism adaptation of one of the spaces within this area of the discussed town.

In addition, one of the goals of the present work is to draw attention to the landscape-related legal problem of unfinished construction projects, particularly troublesome in places that suffer from the deficit of spaces dedicated to leisure activity. A classic example is the ruin of a hotel in Ustka town, discussed in the present article.

\section{Keywords}

Ustka town • tourism development • seaport town • "ghost hotel"

\section{Ustka town: the description of the studied area and the timeline of its historic development}

Located at the mouth of the River Słupia, on the shores of the Baltic Sea, the city of Ustka was originally a fishing hamlet. From the beginning of its existence, the city had a strong connection with the sea. The significance of Ustka for the region increased significantly when the seaport was built within it. In its vicinity, housing estates developed, whose residents mostly worked for the port or port-related services.

The earliest known traces of human settlement in Ustka originate from the turn of the 5th and 6th centuries, as indicated by archaeological research. Local residents were mainly engaged in fishing and related crafts. The development and functioning of the hamlet was related to the development of the nearby town of Słupsk, for which 
Ustka was a seaport [Szymańska 2012]. The oldest part of the hamlet, in the shape of an oval, was located east of the port, in the area of the present Marynarki Polskiej and Kosynierów street [ Kal 2014 ]. From the 14th century onwards, the town has experienced dynamic spatial development, but despite that, it retained the type of buildings characteristic of fishing hamlets. In the same century, the first church in Ustka was built, dedicated to Saint John the Baptist and Saint Michael, and consecrated in 1356. During a later phase of the town's spatial development that took place in the nineteenth century, the temple was dismantled, and its furnishings were transferred to the newly founded church of the Most Holy Saviour [Brzóska E. and A. 2006].

When the town became autonomous - independent of Słupsk - in 1831, this marked the beginning of a period of development in various areas of social and economic life for Ustka. The city began to function as a spa. Initially, it the local patients who used it, mainly coming from Słupsk, but increasingly also tourists from further regions came to visit Ustka, along with the development of tourism and leisure infrastructure. There was a visibly increasing development of tourism offer. New areas were designated for beaches, in 1844 the Bathing Resort Management Board was established, and in 1870, the Sea Bathing Association was created [Kal 2014]. These developments were mainly due to the construction of the railway line in 1878, and the expansion of the accommodation base. In 1911, the Ustka Łazienki (Baths) was built, and the Balneology Centre was established. After the Second World War, efforts were undertaken to restore the function of a spa resort (that had been interrupted by the war). The Municipal National Council passed a resolution on the accession of Ustka to the Association of Polish Health Resorts, and in 1948 the "Statute of the spa town of Ustka, regarding the collection of climate tax for the curative fund of the spa" was passed. In the 1970s, the first sanatoria were established [Szymańska 2012].

The location of the city near the Baltic Sea and associated fishing and shipping operations had a decisive impact on the development of Ustka town. In 1945, the Sea Fisheries Institute in Gdynia took over Ustka shipyards from the hands of the Soviets. In 1951, this establishment received entirely Polish management, and it was then that it was given the name of "Ustka" (changed in 1987 to "Engineer Kwiatkowski"). The shipyard's original activity consisted in the repairs of fishing boats, then, after 1946 it began producing its own fishing boats, gradually expanding its activities to rescue and working boats, manufactured for the needs of the Polish shipbuilding industry. In 1971, there was another expansion of production [Jaskuła 1993]. Despite favourable development prospects, after the transformation of the political system in Poland, the shipyard declared bankruptcy in 2002.

Fishery was an important pillar of the town's development. From the very beginning of the hamlet's existence, its inhabitants were fishing in the Baltic Sea. In 1954, the "Korab" Fishing Services Enterprise was established, with a primary task of the exploitation of the Baltic fisheries. In the following years, the company was gradually expanded and modernized.

The development of the town's spa resort activity has had a significant impact on the shape of the area being developed. In the first half of the 19th century, settlement areas 
began to develop towards the east. New streets were marked out, which gradually filled with typical fisherman cottages and villas built for the needs of the spa resort. A strolling park by the seaside, delineated at that time, made way for today's promenade. The increasing interest of patients in the accommodation base led to low-sized fishermen's huts being replaced with several-storey spa resort villas. To some extent, the increasing numbers of residents and visitors coming to Ustka forced the local government to make necessary investments in its infrastructure. This improved the living conditions in Ustka and resulted in even greater development of the quarter of residential villas and guesthouses.

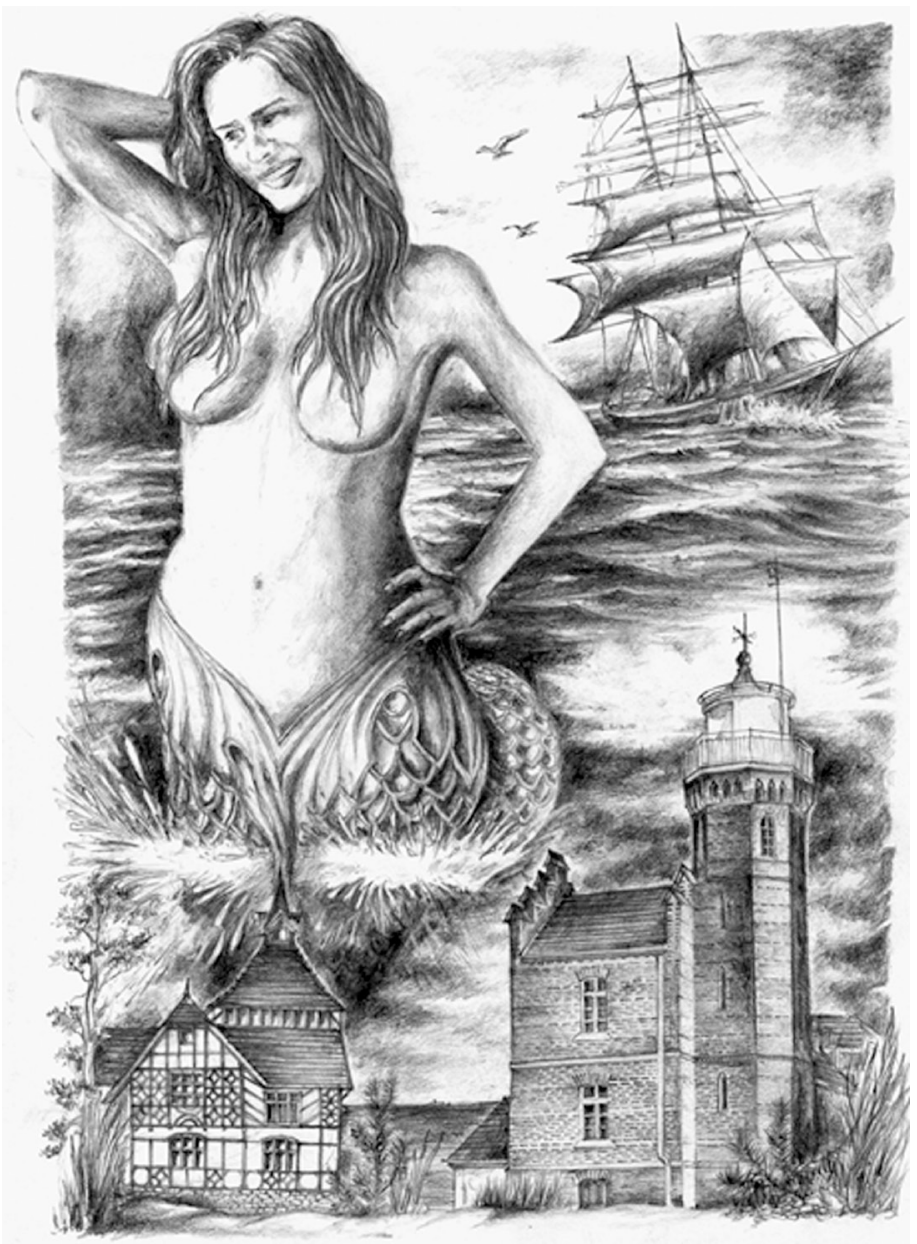

Drawing by the Author

Fig. 1. Symbolic motifs associated with Ustka: The Mermaid, the Baltic Sea, the seaport, tourist ships, fishing boats, the lighthouse, native architecture with its local name associated with the Słupsk region: timbered-frame architecture, or Checkered-House land 


\section{A seaport town}

The town-port relationship is an integral element of the commercial space by the seaside. The development of the town is the driving force for the development of the port and vice versa. The port town fulfils two basic functions: the marine function, and the land-based function, which results from its location. The impact of the port on the town is evident in shaping the face of the city and the entire region [Palmowski et al. 2001].

The town-port system has evolved over many decades. According to Hoyle [1998], there are 6 historical phases of changes in the town-port relationship.

Table 1. Phases of development and evolution of the seaport - port town layout

\begin{tabular}{|c|c|c|c|}
\hline No. & Phases of development & Period & Description \\
\hline I & $\begin{array}{l}\text { Primitive port-town } \\
\text { layout }\end{array}$ & $\begin{array}{l}\text { Until the 19th } \\
\text { century }\end{array}$ & $\begin{array}{l}\text { Spatial and functional unity of the port and the } \\
\text { town }\end{array}$ \\
\hline II & $\begin{array}{l}\text { Development of the } \\
\text { port-town layout }\end{array}$ & $\begin{array}{l}\text { 19th century } \\
\text { and beginning of } \\
\text { 20th century }\end{array}$ & $\begin{array}{l}\text { Fast-paced commercial and industrial growth } \\
\text { sends the port development outside the city } \\
\text { limits. }\end{array}$ \\
\hline III & $\begin{array}{l}\text { Modern town and } \\
\text { industrial port }\end{array}$ & $\begin{array}{l}\text { Mid-20th } \\
\text { century }\end{array}$ & $\begin{array}{l}\text { The development of the industrial function } \\
\text { (particularly, crude oil processing), the } \\
\text { introduction of containers and the so-called } \\
\text { RORO - roll-on/roll-off technology - increases } \\
\text { the demand for space, which leads to the } \\
\text { activation of new areas. }\end{array}$ \\
\hline IV & $\begin{array}{l}\text { Removing the port } \\
\text { further inland (away } \\
\text { from the shoreline) }\end{array}$ & 1960 s to 1980 s & $\begin{array}{l}\text { Changes in maritime transport technologies } \\
\text { lead to the removal of the port industry from } \\
\text { the immediate vicinity of the coastline (further } \\
\text { inland). }\end{array}$ \\
\hline $\mathrm{V}$ & $\begin{array}{l}\text { Renewed development } \\
\text { of the shoreline }\end{array}$ & 1870 s and 1990 s & $\begin{array}{l}\text { The large, modern port occupies large areas of } \\
\text { both water and land; revival of the former port } \\
\text { areas is observed. }\end{array}$ \\
\hline VI & $\begin{array}{l}\text { Renewed link between } \\
\text { the port and the town }\end{array}$ & Since $1980 s$ & $\begin{array}{l}\text { Changing role of the port; renewal of the } \\
\text { ties between the port and the town; urban } \\
\text { revitalization of the old port areas. }\end{array}$ \\
\hline
\end{tabular}

Source: Hoyle [1998]

Port cities in Poland, including Ustka, entered the last phase of development indicated in Table 1 at the turn of the twentieth and twenty-first centuries. City planners began to pay attention to the abandoned, often post-industrial areas in port cities, with a view to assigning them a new function. It is a characteristic feature of seaside areas that the most important criterion when considering investment opportunities is not the size of the given space, but its the proximity of the coastline. The direction of changes in the transformation of port towns illustrates the general trend of contemporary urbaniza- 
tion processes, involving the transformation of city structures, and its degraded areas in particular, as well as the search for their own identity and local features that determine the functional and cultural essence of the city's substance.

In the cities located by the sea, the most attractive investment space is the areas referred to in the literature as a waterfront (an seaside urban, industrial, or port area, facing the water). Due to their functional and cultural value and qualities, the proper development of these waterfront areas is of great importance [Palmowski et al. 2001].

According to Szwankowski and Tubielewicz [1992], port cities perform today a number of the most important functions such as:

1. Traditional port services: navigation services, storage, reloading of goods.

2. Services for passenger and tourist traffic.

3. Logistics and distribution services.

4. Administrative and commercial services.

5. Industrial and environmental services, which concern two kids of industrial services, i.e. industrial and technical (engineering and technical service and ship repairs), industrial (related to cargo) and environmental services (operation of port environment-protection facilities).

\section{Present condition of development of Ustka town in the waterfront zone}

The town of Ustka - in both its origin and its development - is based on close proximity to the Baltic Sea. This is evident in the spatial development of the city, especially in the area of the coastal belt, which covers the northern half of the city. For the purpose of this article, the scope of the analysis was limited to the area shown in the diagram (see Fig. 6).

The main development axis of the analysed area is the seaside promenade, built in 1875 by the Bathing Association on the sea dunes, when the influx of tourists was becoming increasingly intensive. To this day, it remains one of the biggest attractions and one of the most frequented places in Ustka. The promenade stretching at a length of over 1,100 meters starts at the port breakwater, and ends at the Solidarity Trail (Trakt Solidarności). Along the walkway, there are numerous restaurants and bars, hotels, and souvenir shops [http://ustka.travel/a1105-promenada-w-ustce.html, accessed: 4 June 2018].

The analysed area has the character of a spa resort district, which mainly focuses on leisure and recreational functions. Nearly the whole area covered by the study lies within the Ustka spa protection zone "A". Additionally, a small part is located in the spa zone "B". The whole area is characterized by a substantial share of green areas, which according to local standards - should amount to at least $75 \%$.

The analysed district includes areas classified according to their primary purpose:

- areas of services related to tourism traffic and residents' service in the form of boarding houses, hotels, resorts and spas, general services, trade, gastronomy, public services, such as education, public administration, services related to sport and recreation, culture, etc., 
- areas of single-family and multi-family residential buildings,

- areas of planned green spaces,

- areas of public access roads,

- areas of pedestrian routes,

- areas of footpaths and cycling paths,

- areas of internal roads,

- linear or area zones designed for the services of the power grid, including overhead lines, cable lines and transformer stations.

The area discussed here is valuable in terms of environmental protection, nature, landscape and cultural heritage. Therefore, no functions that could potentially violate environmental protection regulations may be placed therein. In the area of the current plan called "Seaside Promenade II" (Nadmorska Promenada Bis), an absolute requirement to protect valuable tree stand as well as valuable flora and fauna sites has been stressed. The area of the attached plan, including "Centre 3" (Centrum 3) and "Centre 3 II" (Centrum 3 Bis) is located within the zone where mineral water occurs, and within the boundaries of the mining area of the therapeutic peat deposit.

The location of the analysed area within the limits of the service strip and the protective zone is linked with the need to obtain the consent of the competent authority of maritime administration, in the case of any kind of activity within its borders. The area of the service strip is an area designated for carrying out works related to the protection of the sea coast and the location of various forms of coastline reinforcements, hydrotechnical and bio-technical structures, as well as devices related to sea navigation and rescue. The service strip is the area of particular flood hazard (Water Law Act of July 20, 2017. Journal of Laws of 2017, item 1566, 2180, of 2018, item 650,710). The abrasive nature of the seashore means that in the future it may be necessary to move the service strip further inland. The forested dunes constitute a natural protective layer, shielding the areas located inland from the flooding by the attacking sea waves [Pasikowski 1970].

The Ustka beach meets high standards of cleanliness and safety, as evidenced by the European "Blue Flag" Quality Certificate awarded in the international program of the Danish Foundation for Environmental Education. It is granted to sites that meet the highest criteria in terms of water quality, environmental management, safety and conducting educational and information activities [http://www.ustka.pl, accessed: 15 June 2018].

One of Ustka's more serious problems is the disproportionate number of tourism offers, in particular accommodation available, in relation to the capacity of the beaches. The final elaboration of the local planning study (the so-called "study of spatial development conditions and directions”) for Ustka [Kiełb-Stańczuk, Jaszczuk-Skolimowska 2001] presents some suggestions for solving this particular problem. The document reads: "It is necessary to enrich the recreational-leisure offer (with the so-called "aqua park", tourist salmon fishing tours, health-rehabilitation stays, business tourism) to redirect some part of the stream of tourists away from the beaches. It is important to create conditions for the development of maritime tourism, to create conditions for 
servicing tourists from Scandinavia as well as welcoming cycling tourism, also from abroad.

The following spa treatment facilities are located within the discussed area:

- The "Joy" ("Radość") Spa resort,

- The "Rainbow" ("Tęcza") Spa resort,

- Natural Medicine Facility,

- "Health resort clinic".

In addition, there are also open areas for spa treatment:

- Spa-resort park with an area of approximately 1.43 ha,

- Hiking routes within the park,

- Coastal promenade,

- An organized stretch of seacoast, about one kilometre long.

In addition to the listed spa facilities, Ustka boasts a very large number of hotels, hostels, camps, and private rental accommodations.

\section{Ustka town's problem with the so-called "ghost hotel", as a representative example of an unfinished construction project}

An unfinished investment project left behind an incomplete building at Wczasowa street, at the end of the seafront promenade. It is a structure that was supposed to be the Hotel of Polish Airlines (LOT). Its construction began in the 1980s. The hotel was supposed to be a modern, state-of-the-art building, in which pioneer heating systems were planned, such as heat pumps, which were a novelty at a time. It was supposed to be equipped with a swimming pool, large conference rooms and an attractive area all around. The construction of the facility was interrupted by the lack of funds in the early 1990s. The condition of the real estate property increasingly deteriorated, from one year to another. Most elements of equipment were stolen or destroyed (windows, radiators, and even tiles were looted). Currently, the building is in private hands, and its poor condition remains unchanged. For a number of years, the changing owners promised to create a water park, casinos, bowling alleys, a marina for yachts and sailboats on the site in question (Fig. 2) [Tomasik 2005]. Unfortunately, none of these promises have been actually made reality [Arszyński 2006].

From the point of view of the development strategy for the city of Ustka, the never finished building of the hotel poses a unique problem. Some of these types of objects can be called "strategic" - that is such for which radical steps must be taken in terms of their purpose, use of the surrounding space, and appearance [Uruszczak 2011]. This is also the case of the said "ghost-hotel" in Ustka, which together with the unused area around it, originally intended for tourism development, discourages walkers, tourists, patients and residents from using adjoining recreational spaces, even if these are correctly arranged. Being located at Wczasowa street, where most of the city's exclusive hotels are also located, this has become a kind of a negative ad for Ustka town (Fig. 3-5). 


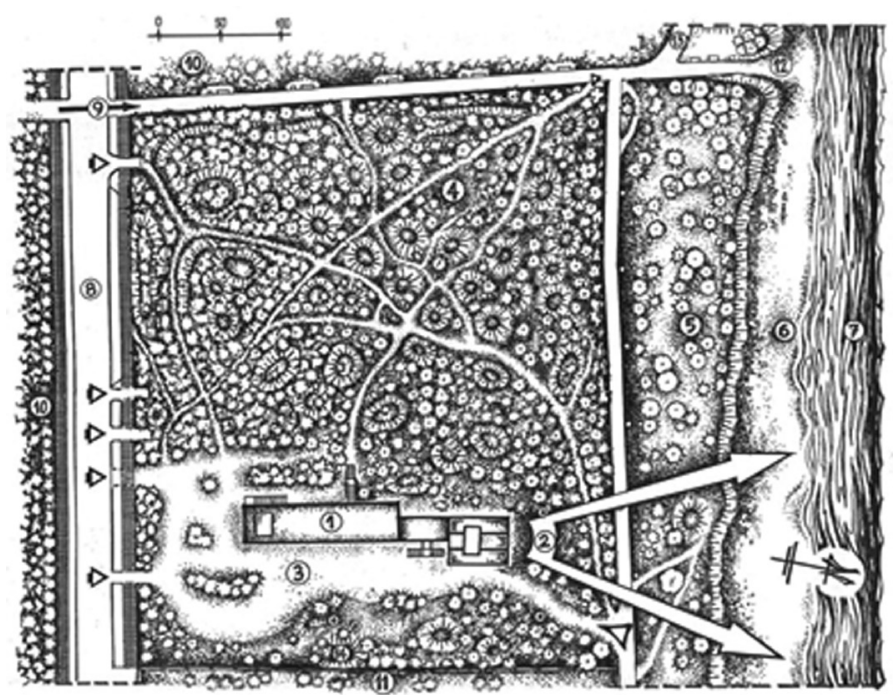

Drawing by the Author, 2018

Fig. 2. Plan of the unused area belonging to the never-completed hotel at Wczasowa street in Ustka. 1 - hotel building, 2 - extensive panorama view from the hotel towards the sea, 3 - empty, irregular spaces, unrealized parking lots, 4 - several-hectare space on forest growing in the dunes, a littered and overgrown area, originally intended for the use as the hotel's own park 5 - front dune, 6 - area in front of the dune (the beach), 7 - sea, 8 - Wczasowa street, 9 - much-frequented walking promenade, 10 - forest or recreational areas, 11 - Sanatorium "Tęcza" " Rainbow" spa resort), overlooking the ruin of the hotel, 12 - exit to beach, 13 - beginning of a walking route leading to the centre of Ustka, 14 unprotected ruins of the hotel's technical basement

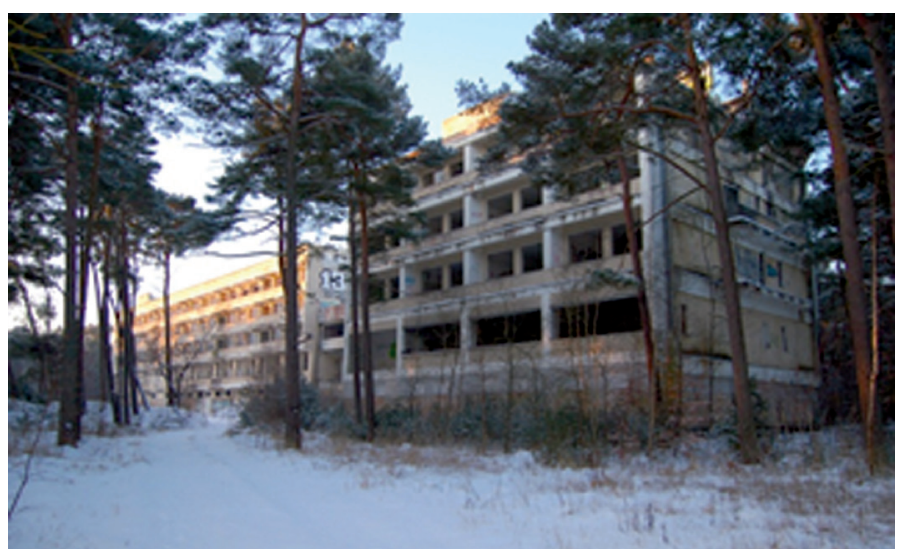

Photo by the Author, February 2018

Fig. 3. The "ghost hotel" in Ustka is an unfinished building by Polish Airlines (LOT); here: the view of the seaside part 


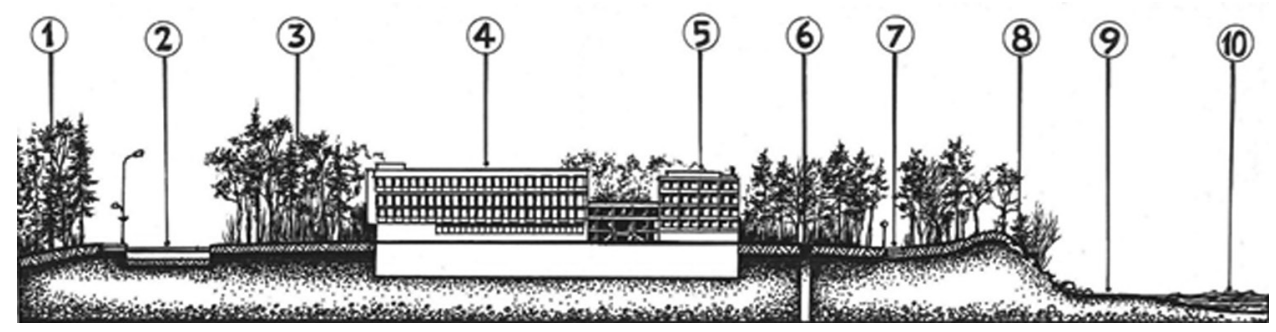

Drawing by the Author

Fig. 4. Schematic drawing of the terrain and layout, starting from wooded areas - 1, adjacent to Wczasowa street - 2), 3 - forest surrounding the hotel, 4 - front part of the hotel, 5 part of the hotel with viewing platform, 6 - heat pumps, 7 - walking promenade, 8 - cliff edge, 9 - beach, 10 - sea

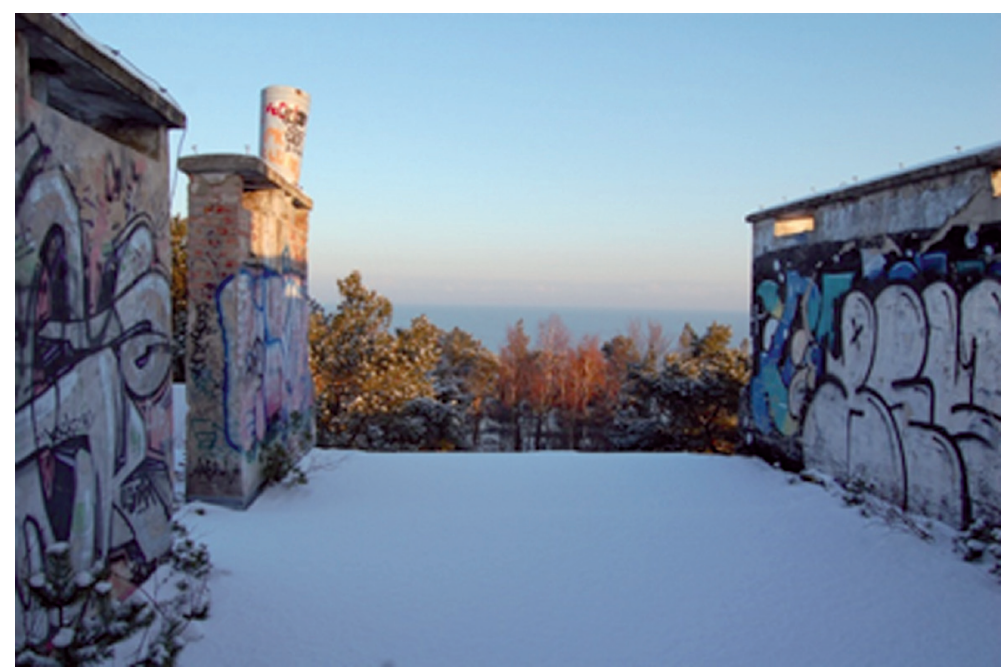

Photo by the Author, February 2018

Fig. 5. View from the terrace of the "ghost hotel" towards the sea

\section{Assessment of the development of the eastern part of Ustka's seaside belt, from the point if view of tourism attractiveness}

Based on the information we collected, we were able to present the results in the form of a tabulated list of individual criteria for the valorisation performed. Each of the indicated elements of the landscape and tourism attractiveness of a typical tourismoriented seaside town and spa resort, such as Ustka, has been assessed. This is shown in Table 2. 


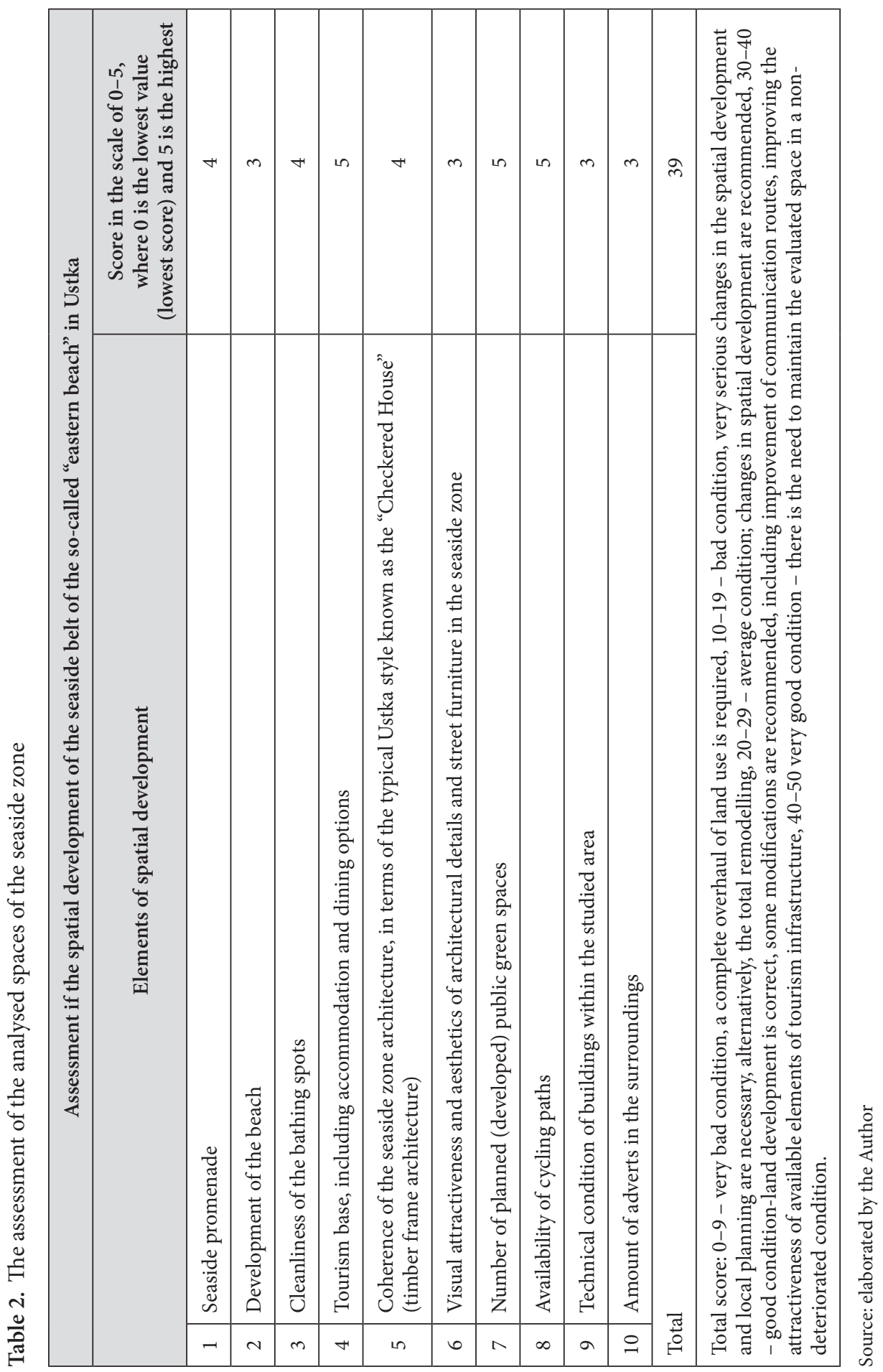




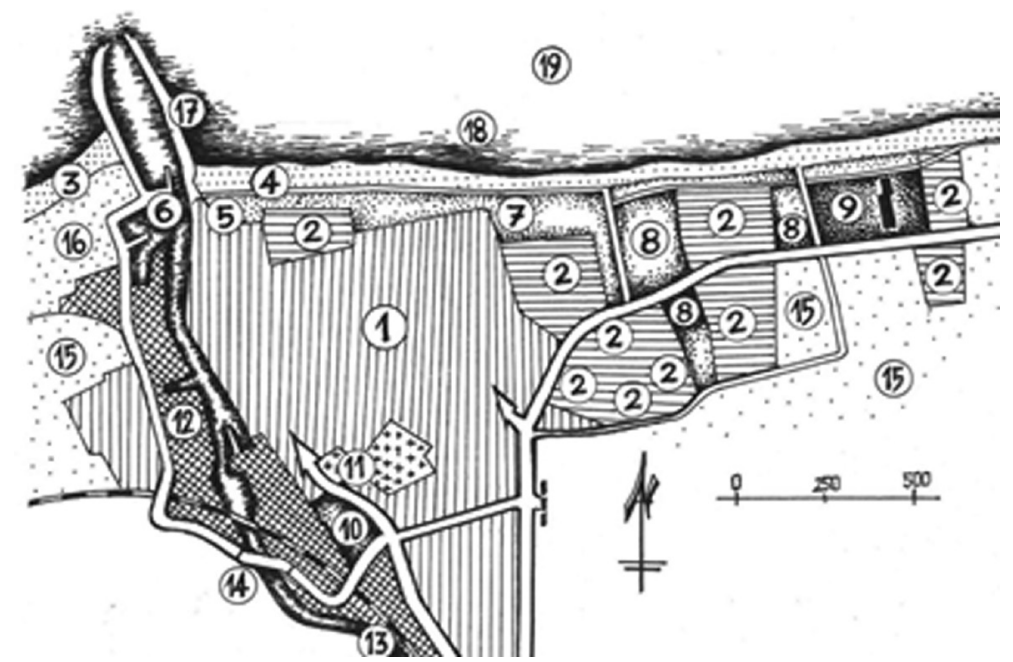

Drawing by the Author

Fig. 6. Diagram of the spatial divisions of the area of the Ustka town, showing in the downtown and seaside part a clear shortage of beaches and publicly accessible green areas. 1 - dense urban development, 2 - areas of hotels, boarding houses, holiday resorts, 3 - the socalled "western beach" separated from the city centre by the Słupia river, 4 - the so-called "eastern beach", 5 - location of the lighthouse, which is one of the symbols of Ustka town, 6 - a moveable footbridge connecting the western and eastern part of the city, 7 Chopin's Park, 8 - ropes course on the dunes and open-air gym, 9 - green space adjoining the "ghost hotel", 10 - public square at Marynarki Polskiej and Dworcowa streets, 11 the church and cemetery, 12 - area of the disused, closed-down shipyard Ustka SA, 13 - Słupia river, 14 - vehicle traffic bridge on the Słupia river, 15 - forest areas, 16 -former military buildings and facilities, 17 - pier along with the Ustka Mermaid - the symbol of the city, 18 - artificial (man-made) underwater reef, 19 - the Baltic Sea

\section{Conclusions}

The collected materials and information available in legal acts, literature on the subject but also resulting from in-situ studies led us to formulating conclusions.

The nature of Ustka and its development results from the town's coastal location, which is associated with a wealth of natural, landscape and curative values. An important aspect in the specific development of the town is the fact that it still housed its own shipyard, as late as until the twenty-first century. This, in turn, was connected with the mouth of the river Słupia where it joined the Baltic Sea - having an impact on the clear division of recreational areas, as well as the urbanized area of the town, into the so-called "eastern part" and "western part". It should be noted that there is a large disproportion between the tourists' interest in these two shores of the Słupia estuary (Fig. 6). This fact results also from the communication disadvantages between the two areas. 
Located within the boundaries of the coastal belt, the analysed area is particularly exposed to the impact of environmental and anthropogenic factors. A kind of a buffer zone, composed of planned greenery (Park Uzdrowiskowy and Park Chopina) and natural greenery between urbanized areas and the beach and dunes constitutes an interesting aspect from the point of view of spatial development of the coastal belt.

The western beach and the region of the degraded areas between Wczasowa street and the Baltic Sea shore require serious action in terms of their revitalization and subsequent promotion. It is necessary to reduce the perceived disproportion between the resources of tourism offers (mainly accommodation) and the limited capacity of Ustka beaches.

\section{References}

Arszyński B. 2006. Ruina straszy. Głos Słupski, 157, 07.07.2006, 6.

Brzóska E. i A. 2006. Ustka, jakiej nie znamy, wyd. II popr. Wydawnictwo Grawipol, Słupsk.

Hoyle B. 1998. The redevelopment of derelict port areas. The Dock \& Harbour Authority. Foxlow Publications, London, 887, 47.

Jaskuła J. 1993. Ustka - Bedeker, Ustka, 31-32.

Kal E. 2014. Ustka dawno, dawniej, dziś. Architektura i Urbanistyka, Ustka, 9-11.

Kiełb-Stańczuk M., Jaszczuk-Skolimowska B. 2001. Studium uwarunkowań i kierunków zagospodarowania przestrzennego miasta Ustka. Kierunki i polityka przestrzenna. Stargard Gdański.

Palmowski T. 1996. Przestrzenne układy komunikacyjne w regionie nadmorskim. Kryteria form modelowych i perspektywy transformacji. Uniwersytet Gdański, Gdynia, 237-238.

Palmowski T. i in. 2001. Przemiany przestrzeni miejskiej miast portowych na przykładach Gdańska i Gdyni. XIV Konserwatorium Wiedzy o Mieście. Łódź, 33-35.

Pasikowski J. 1970. Ochrona brzegu morskiego. [w:] Przyroda i krajobraz Ziemi Koszalińskiej, red. J. Cieplik, J. Narkowicz i R. Śpiewakowski. Koszalin.

Szwankowski S., Tubielewicz A. 1992. Planowanie strategiczne w portach morskich. Wydawnictwo Instytutu Morskiego, Gdańsk-Szczecin, 10.

Szymańska W. 2012. Ekonomiczne i organizacyjne aspekty funkcjonowania polskich uzdrowisk. Akademia Pomorska w Słupsku, Słupsk, 209-215, 220.

Tomasik K. 2005. Delfin odpłynął. Głos Słupski, 110, 13.05.2005, 5.

Uruszczak M. 2011. Problem prawny i krajobrazowy nieukończonej budowy - wybrane zagadnienia i przykłady małopolskie. Architektura Krajobrazu, 4(33), Uniwersytet Przyrodniczy we Wrocławiu, 94-99.

Ustawa z dnia 20 lipca 2017 r. - Prawo wodne, Dz.U. z 2017 r., poz. 1566.

http://www.ustka.pl (accessed: 15.06.2018).

http://ustka.travel/a1105-promenada-w-ustce.html (accessed: 04.06.2018).

Dr inż. arch. Michał Uruszczak

Uniwersytet Rolniczy w Krakowie

Katedra Gospodarki Przestrzennej i Architektury Krajobrazu

ul. Balicka 253c, 30-198 Kraków

e-mail: muruszczak@op.pl 